\title{
Redesigning Ergonomic Vertical Folding Desk in an Apartment Room using Anthropometric Approach
}

\author{
Handoyo*, Anindyo Fikri Wiraputra \\ Department of Industrial Engineering, Universitas Pembangunan Nasioanal “Veteran” Surabaya, \\ Indonesia
}

*Corresponding author:

E-mail: handoyo@gmail.com

\begin{abstract}
The use of a desk is generally big and can only be used for learning and does not have any additional functions; it causes the table to consume a lot of space in a room. The occupancy of the vertical occupancy is minimal, given the numerous availability. This design hopes to meet the needs of users who live in a place with narrow areas such as apartments, boards, houses, and other living rooms to do some activities related to the function of furniture that will be designed. With the increasing interest of people living in apartments, it is essential to consider furniture that will be used in a relatively narrow room. Thus, it is needed to overcome the conditions of the confined room. This research aims at redesigning an ergonomic and innovative folding desk in the apartment room, to provide comfort in its users. In improving the folding desk, it is hoped that this proposed folding desk will be more ergonomic and can be used daily. The results show that the recommended size for the ergonomic desk is $62 \mathrm{~cm}$ wide, $163 \mathrm{~cm}$ long, and $29 \mathrm{~cm}$ high; also, the recommended size of the seat is $50 \mathrm{~cm}$ high.
\end{abstract}

Keywords: Redesigning, folding desk, ergonomic, anthropometric approach

\section{Introduction}

A desk is an essential means of support in the process of human activities (Kristanto \& Saputra, 2011). The use of desks are generally big and can only be used for learning and do not have other additional functions. Hence, it spends much space in a room, whereas the wide occupancy in vertical residences is very limited to consider its furniture. This design is expected to meet the needs of users who live in residential areas with a narrow or limited area such as apartments, boarding houses, flats, and other habitable spaces to perform several activities related to the function of furniture to be designed (Raymondus, 2013).

The apartment itself has ten characteristics explained by Harianto (2014). Those characteristics are built in more than two floors and are usually a vertical building, consists of some units on one floor, flexible in achieving maximum utilization of space, efficient and effective also ecofriendly, has shared facilities that are not necessarily owned by housing, generally, there are commercial areas in the apartment building or environment, vertical circulation in the form of stairs or lifts and horizontal circulation, security, peace, and privacy are guaranteed, easy and fast access to reach existing facilities; also structures and building materials can last for a long time.

Look at to its function there are three functions of apartment, those are primary functions, as a living place, secondary function which is added in an apartment to give comfort towards its primary function, and complementary function which supports the primary and secondary functions (Eka, et al., 2016). Besides, there are four types based on the apartment unit. Those are studio, a family apartment consisting of one, two, or three rooms, loft, and penthouse (Cahyaningtyas \&

\section{How to cite:}

Handoyo, \& Wiraputra, A. F. (2020). Redesigning ergonomic vertical folding desk in an apartment room using anthropometric approach. 1 ${ }^{\text {st }}$ International Conference Eco-Innovation in Science, Engineering, and Technology. NST Proceedings. pages 226-232. doi: 10.11594/ nstp.2020.0536 
Rahardjo, 2016). Based on its building mass shape, an apartment can be classified into two categories; those are slab apartment and tower apartment (Utami, et al., 2015).

In conducting this study, the researchers use an anthropometry approach to redesign the folding desk used in the apartment. Harrianto (2010) confirms that anthropometry is the measurements of the human body naturally both in carrying out static activities (actual size) and dynamic (adjusted to work). Anthropometry data preparation needs to pay attention to variability because several factors affect the size of the human body (Jennie, et al., 2017). Herawati \& Pawitra explains (2013) anthropometric data, which is used as a basis for product design are generally grouped into two types, namely static anthropometry (structural) and dynamic anthropometry (functional).

The application of anthropometric data can be made if the average standard (mean) and standard deviation (SD) are available from a normal distribution (Nurrohman \& Yohanes, 2017). There are three principles in the use of those terms, namely the design of facilities based on extreme individuals, the design of facilities that can be adjusted, and the design of facilities based on the average size of the user (Pranindo \& Nurkertamanda, 2013).

The design of work equipment based on anthropometric data of the user aims to reduce the level of work fatigue, improve work performance and minimize the potential for work accidents (Jennie, et al., 2017). The product design itself is divided into seven steps that each have their method. The seven steps are purpose classification, function determination, needs arrangement, characteristics determination, improvement details, alternative construction, and alternative evaluation (Priyatna \& Wiyancoko, 2014). Furthermore, product development is a series of activities that begin with the analysis of perceptions and opportunities, then end with the stages of production, sales, and delivery (Ulrich \& Epinger, 2001).

Based on the condition mentioned above, the researcher tries to redesign an ergonomic folding desk to fit in the limited space in the apartment. The ergonomics discipline, in particular, will learn the limitations of the human ability to interact with technology and homemade products (Raymondus, 2013). There are four main objectives of ergonomics, namely maximizing employee efficiency, improving work health and safety, encouraging work safely, comfortable and vibrant, and maximizing work form.

It is also essential to have data homogeneity since it cannot be inserted in the next calculation if the data are not equal. Hence, the data should be tested to meet the requirement. The data also should be adequate to be calculated to avoid data retake. If $\mathrm{N}^{\prime}<\mathrm{N}$ so that the data are considered adequate to be measured. On the other hand, if $\mathrm{N}^{\prime}>\mathrm{N}$ so that the data are less adequate to be calculated. Meaning that the data retake necessary to do. To distribute the data, it needs a normal distribution with the formula of the bell-shaped symmetric towards $x=\mu$. This normal distribution or normal curve is also called Gauss distribution with the following formula, where:

$$
f(x)=\frac{1}{\sigma \sqrt{2 \pi}} e^{-1 / 2}\left(\frac{x-\mu}{\sigma}\right)^{2}
$$

\section{Research Method}

This study was conducted at Menara Rungkut City Surabaya in January 2019 until the required data was sufficient. The variables in this study are folding desk as a bound variable and anthropometric data, desk design, and questionnaire as an independent variable. The researchers also used a questionnaire to provide easiness to respondents in giving opinions and answering questions since it is provided with some options to be chosen (Bimo, 2010). Problem-solving steps that can be taken in this study to get the results or solutions from the research to be carried out from beginning to end. 


\section{Result and Discussion}

After investigating the data, the researcher classified 40 users who live in Menara Rungkut Apartment Surabaya based on their Hand Reach (HR), Hand Span (HS), and Elbow Height (EH) as it is shown in the table below:

Table 1. User anthropometric data

\begin{tabular}{|c|c|c|c|}
\hline \multirow{2}{*}{ Number of user } & \multicolumn{3}{|c|}{ Body Dimension (cm) } \\
\hline & HR & HS & EH \\
\hline 1 & 73 & 180 & 37 \\
\hline 2 & 72 & 187 & 34 \\
\hline 3 & 76 & 189 & 30 \\
\hline 4 & 76 & 181 & 35 \\
\hline 5 & 75 & 190 & 36 \\
\hline 6 & 76 & 180 & 31 \\
\hline 7 & 75 & 187 & 31 \\
\hline 8 & 77 & 182 & 34 \\
\hline 9 & 74 & 183 & 33 \\
\hline 10 & 74 & 189 & 35 \\
\hline 11 & 74 & 190 & 36 \\
\hline 12 & 75 & 180 & 36 \\
\hline 13 & 75 & 191 & 32 \\
\hline 14 & 76 & 184 & 34 \\
\hline 15 & 77 & 182 & 30 \\
\hline 16 & 73 & 180 & 36 \\
\hline 17 & 73 & 188 & 32 \\
\hline 18 & 76 & 188 & 33 \\
\hline 19 & 76 & 182 & 34 \\
\hline 20 & 75 & 184 & 31 \\
\hline 21 & 76 & 187 & 34 \\
\hline 22 & 73 & 186 & 37 \\
\hline 23 & 74 & 180 & 37 \\
\hline 24 & 75 & 181 & 35 \\
\hline 25 & 78 & 186 & 37 \\
\hline 26 & 73 & 182 & 34 \\
\hline 27 & 72 & 190 & 35 \\
\hline 28 & 75 & 182 & 33 \\
\hline 29 & 77 & 190 & 36 \\
\hline 30 & 74 & 182 & 32 \\
\hline 31 & 73 & 182 & 33 \\
\hline 32 & 75 & 181 & 35 \\
\hline 33 & 76 & 181 & 32 \\
\hline 34 & 76 & 187 & 37 \\
\hline 35 & 75 & 184 & 37 \\
\hline 36 & 75 & 182 & 34 \\
\hline 37 & 76 & 190 & 31 \\
\hline 38 & 77 & 185 & 34 \\
\hline 39 & 73 & 189 & 34 \\
\hline 40 & 72 & 185 & 36 \\
\hline$\sum \mathrm{X}$ & 2915 & 7389 & 1363 \\
\hline
\end{tabular}




\section{Initial Desk Design}

The initial table design in Menara Rungkut apartment can be seen in the following picture:

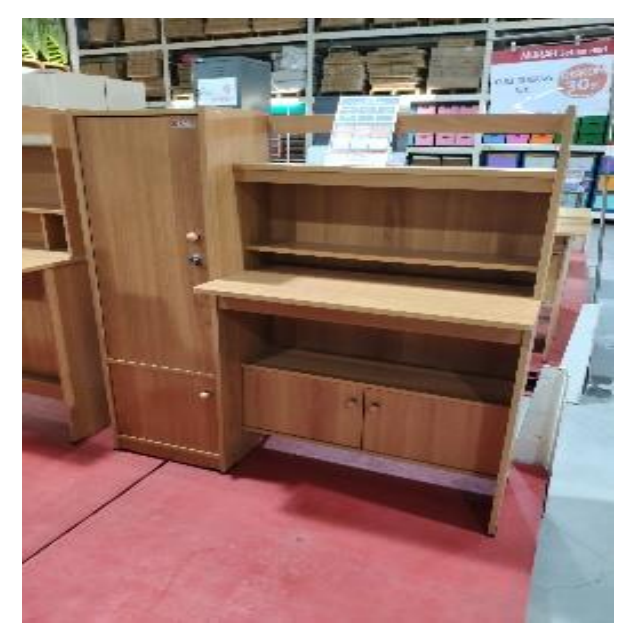

Figure 1. Initial desk design

In the figure displayed above, the desk height $50 \mathrm{~cm}$ high, the desk width is $40 \mathrm{~cm}$ wide, and the desk length is $60 \mathrm{~cm}$ long.

\section{Proposed desk design}

Data homogeneity test

Based on the chart of data homogeneity test of the apartment users, the results shown in the following table:

Table 2. The result of data homogeneity test

\begin{tabular}{|c|c|c|c|c|c|c|c|}
\hline $\begin{array}{l}\text { Body Di- } \\
\text { mension }\end{array}$ & $\begin{array}{l}\text { BKA } \\
(\mathrm{cm})\end{array}$ & $\begin{array}{l}\text { BKB } \\
(\mathrm{cm})\end{array}$ & $x(\mathrm{~cm})$ & $\sum \mathrm{X}(\mathrm{cm})$ & $\begin{array}{c}\text { Minimal } \\
\text { Data }\end{array}$ & $\begin{array}{c}\text { Maximal } \\
\text { Data }\end{array}$ & Notes \\
\hline HR & 86.07 & 56.67 & 72.87 & 6.6 & 72 & 78 & Homogen \\
\hline HS & 210.34 & 159.1 & 184.72 & 12.81 & 180 & 191 & Homogen \\
\hline EH & 42.47 & 25.67 & 34.07 & 4.2 & 30 & 37 & Homogen \\
\hline
\end{tabular}

\section{Data adequacy test}

By applying a 5\% level of accuracy, 95\% eligibility rate, the data adequacy test shown below:

$$
N^{\prime}=\left[\frac{k / s \sqrt{N \sum \mathrm{X}^{2}-\left(\sum \mathrm{X}\right)^{2}}}{\sum \mathrm{X}^{2}}\right]^{2}
$$

The value of $\mathrm{k}=2$ and the value of $\mathrm{s}=0,05$

If $\mathrm{N} ' \leq \mathrm{N}$ then the data is adequate to do the design

If $N$ ' $\geq N$ then the data is not enough to do the design

The data from the measurement result is sufficient to design the product. The following table is the result of the data adequacy test. 
Table 3. The result of the data adequacy test

\begin{tabular}{|c|c|c|c|c|}
\hline No. & Body Dimension & $\mathbf{N}$ & $\mathbf{N}^{\prime}$ & Notes \\
\hline 1 & Hand Reach (HR) & 40 & 0.0064 & Adequate data \\
\hline 2 & Hand Span (HS) & 40 & 0.0009 & Adequate data \\
\hline 3 & Elbow Height (EH) & 40 & 0.0324 & Adequate data \\
\hline
\end{tabular}

\section{Determining the Percentile}

Here the researchers determined the size desk by adjusting the percentile.

- Determine the width of the table

HR of the desk $=\bar{x}-P_{5}(\mathrm{SD})=72,87-1,645(6,6)=62 \mathrm{~cm}$

The width of the recommended desk is $62 \mathrm{~cm}$ wide

- Determine the length of the table

HS of the desk $=\bar{x}-P_{5}(\mathrm{SD})=184,72-1,654(12,81)=163 \mathrm{~cm}$

The length of the recommended desk is $163 \mathrm{~cm}$ long

- Determine the height of the table

$\mathrm{EH}$ of the desk $=\bar{x}+$ Tolerance $=24,17+5=29 \mathrm{~cm}$

The height of the recommended desk is $39.07 \mathrm{~cm}$ high

\section{Planning the design of recommended folding desk}

The proposed folding desk for users at age 19-40 years was $62 \mathrm{~cm}$ wide for the desk width, $163 \mathrm{~cm}$ long for the desk length, $29 \mathrm{~cm}$ high for the desk height, and $50 \mathrm{~cm}$ high for recommended seat height.

Table 4. The result of the questionnaire towards the recommended folding desk

\begin{tabular}{|c|c|c|c|c|c|c|c|}
\hline \multirow{2}{*}{ No. } & \multirow{2}{*}{ Attribute } & \multicolumn{5}{|c|}{ Criteria } & \multirow{2}{*}{$\begin{array}{l}\text { To- } \\
\text { tal }\end{array}$} \\
\hline & & 1 & 2 & 3 & 4 & 5 & \\
\hline 1 & The desk height is suitable with sitting position & - & - & 13 & 20 & 7 & 40 \\
\hline 2 & $\begin{array}{l}\text { The desk width is suitable with the user's hand span to } \\
\text { front }\end{array}$ & - & - & 17 & 18 & 5 & 40 \\
\hline 3 & $\begin{array}{l}\text { The desk length is suitable with the user's hand span to } \\
\text { the side }\end{array}$ & - & - & 9 & 25 & 6 & 40 \\
\hline 4 & The desk material is durable and safe for the users & - & - & 19 & 14 & 7 & 40 \\
\hline 5 & The flexibility when it is not used & - & - & - & 24 & 16 & 40 \\
\hline 6 & The desk is having some functions & - & - & 8 & 22 & 10 & 40 \\
\hline & Total & - & - & 66 & 125 & 55 & 240 \\
\hline
\end{tabular}


The table above is the result of the questionnaire, which is responded by forty occupants living in Menara Rungkut Apartment, Surabaya. By applying the analysis of the data analysis, the proposed folding desk can be seen in the following figure:

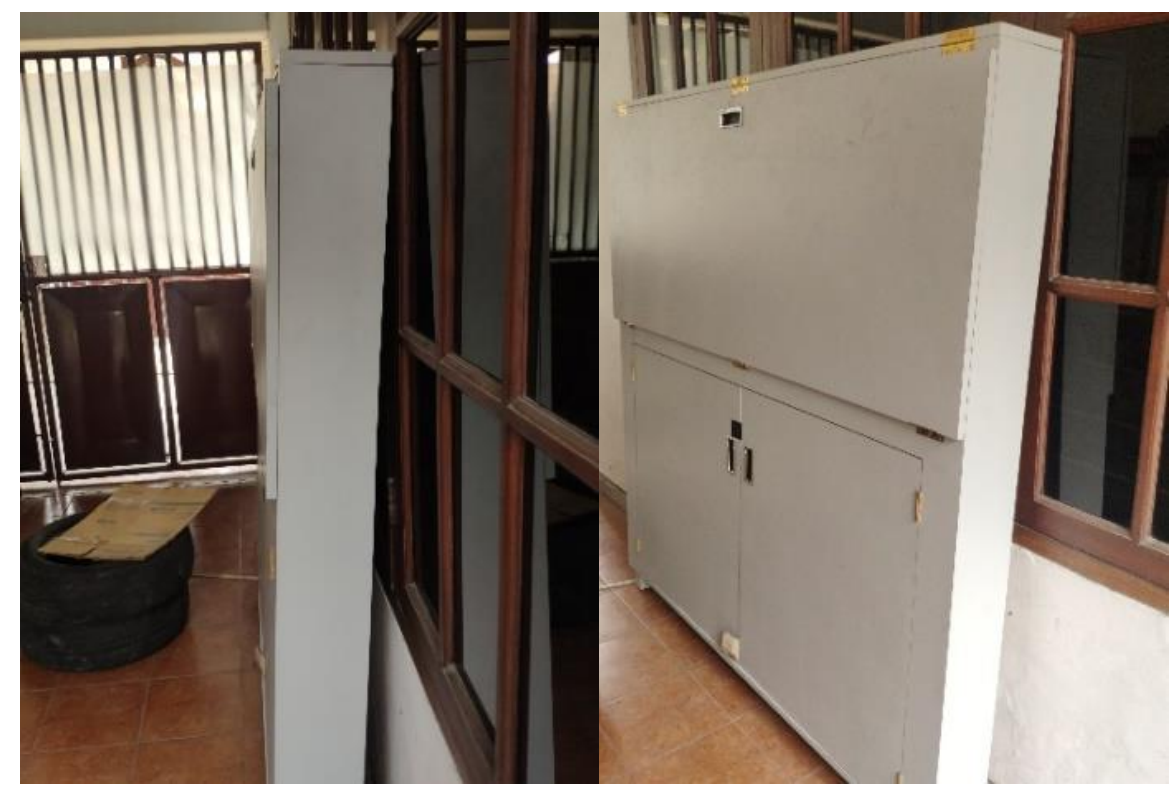

Figure 2. The proposed folding desk design in the apartment

Compare to the initial desk design, the proposed folding desk design is much more appropriate for people living in the apartment since the size is adequate, safe, and healthy to its users. The comparison between the initial design and proposed design is shown in the following table:

Table 5 . The result of the questionnaire of the initial design

\begin{tabular}{|c|c|c|c|c|c|c|c|}
\hline \multirow[b]{2}{*}{ No. } & \multirow[b]{2}{*}{ Attribute } & \multicolumn{5}{|c|}{ Criteria } & \multirow[b]{2}{*}{ Total } \\
\hline & & $\mathbf{1}$ & 2 & 3 & 4 & 5 & \\
\hline 1 & $\begin{array}{l}\text { The desk height is suitable with sitting posi- } \\
\text { tion }\end{array}$ & 24 & 11 & 5 & - & - & 40 \\
\hline 2 & $\begin{array}{l}\text { The desk width is suitable with the user's } \\
\text { hand span to front }\end{array}$ & - & 19 & 11 & 10 & - & 40 \\
\hline 3 & $\begin{array}{l}\text { The desk length is suitable with the user's } \\
\text { hand span to the side }\end{array}$ & 10 & 14 & 16 & - & - & 40 \\
\hline 4 & $\begin{array}{l}\text { The desk material is durable and safe for the } \\
\text { users }\end{array}$ & - & 15 & 17 & 8 & - & 40 \\
\hline 5 & The flexibility when it is not used & 14 & 11 & 8 & 7 & - & 40 \\
\hline 6 & The desk is having some functions & 21 & 18 & 1 & - & - & 40 \\
\hline & Total & 69 & 88 & 58 & 25 & - & 240 \\
\hline
\end{tabular}


Table 6. The result of questionnaire of the proposed design

\begin{tabular}{|c|c|c|c|c|c|c|c|}
\hline \multirow{2}{*}{ No. } & \multirow{2}{*}{ Attribute } & \multicolumn{5}{|c|}{ Criteria } & \multirow{2}{*}{ Total } \\
\hline & & 1 & 2 & 3 & 4 & 5 & \\
\hline 1 & $\begin{array}{l}\text { The desk height is suitable with sitting posi- } \\
\text { tion }\end{array}$ & - & - & 13 & 20 & 7 & 40 \\
\hline 2 & $\begin{array}{l}\text { The desk width is suitable with the user's } \\
\text { hand span to front }\end{array}$ & - & - & 17 & 18 & 5 & 40 \\
\hline 3 & $\begin{array}{l}\text { The desk length is suitable with the user's } \\
\text { hand span to the side }\end{array}$ & - & - & 9 & 25 & 6 & 40 \\
\hline 4 & $\begin{array}{l}\text { The desk material is durable and safe for the } \\
\text { users }\end{array}$ & - & - & 19 & 14 & 7 & 40 \\
\hline 5 & The flexibility when it is not used & - & - & - & 24 & 16 & 40 \\
\hline 6 & The desk is having some functions & - & - & 8 & 22 & 10 & 40 \\
\hline & Total & - & - & 66 & 125 & 55 & 240 \\
\hline
\end{tabular}

\section{Conclusion}

The results showed that an ergonomic folding desk design is the design that has $62 \mathrm{~cm}$ wide, $163 \mathrm{~cm}$ long, and $29 \mathrm{~cm}$ high. Besides that, the seat height should have $50 \mathrm{~cm}$ high. Besides, this desk has several storage functions under the desk pad that are used to store books, stationery, dining places, luggage, and other equipment that support learning activities at school, as well as the legs that can be folded when not in use. Thus, its wide use needs to be considered.

\section{Acknowledgment}

This research will not be accomplished without the support of the rector, the dean of the industrial engineering department, my research partner, Anindyo, also my daughter, who helped this paper to be translated.

\section{References}

Anwar, M. (2014). Pengantar kewirausahaan (teori dan aplikasi). Jakarta: Kencana.

Bimo, W. (2010). Introduction to general psychologists. Yogyakarta: CV Andi Offset

Cahyaningtyas, A. D., \& Rahardjo, S. (2016). Use of the space saving concept for studio type apartments in Bandung. Jurna I IDEALOG, $1(2), 178-192$

Harianto, G. (2014). Freedom of space in apartment units. E-Journal Graduate Unpar, 1(2), 125-143

Harrianto, R. (2010). Occupational health textbook. Jakarta: EGC

Herawati, L, \& Pawitra T. A. (2013). Evaluation of anthropometric data for children aged 4-6 years in east java and applications in the design of learning facilities in schools. Surakarta: Muhammadiyah University of Surakarta press

Jennie, H., Mariaiana, \& W., Dodi, W. (2017). Anthropometric and ergonomics study of early childhood education furniture design in 34 years in Siwalankerto. Intra Journal, 5(2), 449-459

Kristanto, A., \& Saputra, D. A. (2011). Designing ergonomic work tables and chairs at cutting work stations as efforts to increase productivity. Journal of Industrial Engineering, 10(2), 78 - 87

Nurrohman \& Yohanes A. (2017). Design of jenang presses with anthropometry and ergonomics methods (Case study in UKM AGAPE Pemalang). Semarang: Stikubank University Semarang.

Pranindo, A., \& Nurkertamanda, D. (2013). Redesign of the bamboo bent lamination chair with the design guidelines collaboration framework (DGLS-CF) concept towards sustainable product. Scientific Journal of Industrial Engineering, 12 (1), 54-61

Priyatna, P., \& Wiyancoko, D. (2014). Design of multifunctional beds. Bandung Institute of Technology.

Raymondus, E. F. (2013). Designing ergonomic work procedures table based on anthropometric data for work time measurement practicum. Pontianak: Tanjungpura University

Ulrich, K. T., \& Eppinger, S. D. (2001). Product design and development. Jakarta: Salemba Teknika

Utami, E. (2015). The kano model approach to quality function deployment to improve the quality of teaching and learning activities. Scientific Journal of Industrial Engineering, 14(2), 187-195

Eka, V., Aji, N. E. P., Nugraha, H. I., Eulalia, M., Chynda, I, V. (2016). design aspects related building visual function in tamansari panoramic apartment in the city of Bandung. Journal of Reka Karsa, 4(1), 1-10 